\title{
Coulisses
}

Revue de théâtre

15 | Hiver 1997

Varia

\section{Une musique qui construit un temps poétique}

\section{Michèle Raineri}

\section{OpenEdition}

Journals

Édition électronique

URL : http://journals.openedition.org/coulisses/5109

DOI : 10.4000/coulisses.5109

ISSN : 2546-9460

\section{Éditeur}

Presses universitaires de Franche-Comté

\section{Édition imprimée}

Date de publication : 1 janvier 1997

Pagination : 48

ISSN : 1150-594X

\section{Référence électronique}

Michèle Raineri, «Une musique qui construit un temps poétique », Coulisses [En ligne], 15 | Hiver 1997, mis en ligne le 26 avril 2019, consulté le 31 octobre 2019. URL : http://journals.openedition.org/ coulisses/5109; DOI : 10.4000/coulisses.5109

Ce document a été généré automatiquement le 31 octobre 2019

Coulisses 


\title{
Une musique qui construit un temps poétique
}

\author{
Michèle Raineri
}

1 J'ai apprécié les moments instrumentaux, ces tableaux colorés de musiciens dans la salle, en déplacements ou en tableaux sur la scène. Images qui sculptent l'espace dans un temps musical, qui épongent l'énergie dramatique. A ces moments-là, la musique n'est ni illustrative, ni redondante, ni dramatique. Elle n'exprime pas; elle construit une poésie du temps, d'un temps poétique, presque théâtral. Elle « apaise » cependant, ou plutôt, elle laisse le spectateur dans l'écho du texte de Claudel. Elle rend le texte humainement supportable. Quant aux moments musicaux vocaux, la novice chante avec une fraîcheur vive et enfantine ce cantique comme un chant du folklore de l'enfance. Il devient VIE. La chanson de Violaine mourante est le temps enfoui de l'enfance, avant l'épreuve. Elle est arrachement à la vie. Elle devient MORT.

\section{AUTEURS}

\section{MICHÈLE RAINERI}

Professeur d'éducation musicale, IUFM Epinal 